\title{
Mitigasi dampak kebisingan bandara terhadap kehidupan pemukiman sekitar bandara SSK II Pekanbaru
}

\author{
Eko Hendi Saputra ${ }^{1}$, Yusni Ikhwan Siregar ${ }^{2}$, Hafidawati $^{3}$ \\ ${ }^{1}$ Staff Perumahan dan Kawasan Pemukiman Kabupaten Kepulauan Meranti. \\ ${ }^{2}$ Dosen Pascasarjana Ilmu Lingkungan Program Pascasarjana Universitas Riau. \\ ${ }^{3}$ Dosen Teknik Lingkungan Program Sarjana Universitas Riau. \\ *Correspondent email : saputraekohendi@gmail.com
}

\begin{abstract}
This study aims to determine the level of noise caused by flight activities at Sultan Syarif Kasim II Airport Pekanbaru, analyze noise levels that occur due to flight activities at Sultan Syarif Kasim II Airport Pekanbaru and analyze efforts to control the negative impact of airport noise on the living environment of community settlements. around Sultan Syarif Kasim II Airport Pekanbaru. This research uses field observation method, which is making direct observations at the research location by looking at the condition of the location and the suitability of the location which is the sampling point of the study (the noise level boundary at Sultan Syarif Kasim II Airport). Observations were made for 16 hours (Ls) at an interval of $06.00-22.00$. Measurement of sound pressure level is carried out on holidays (Sunday) and weekdays (Monday), which starts on November 1, November 2, November 8, and November 9, 2020, which is carried out in residential areas around Sultan Syarif Kasim II Airport Pekanbaru, which are spread across 6 measurement points where the measurement of sound pressure level is done in duplicate, namely: Jl. Kaswari (point 1), Jl. Rawa Indah II (Point 2), Jl. Rawa Indah III (Point 3), Jl. Cinnamon (Point 4), Jl. Pahlawan Kerja gg.Pala 49 (Point 5) and Jl. Nur Asiyah (Point 6) The results of the processing of noise measurement data were made of a mapping model using surfer 11 software and to clarify the noise description at the sampling location, the map of the results of surfer 11 software processing was plotted on the airport area map. Based on the results of measurements of noise levels around Sultan Syarif Kasim II airport, it is known that the location of point 1 (Jl. Rawa Indah II) experienced the highest noise exposure. These results indicate the location of point 1 should receive serious attention for the people who live around the airport, because the impact of airport noise has the potential to negatively affect the lives of residential communities. From the observations, it was also known that the level of noise attenuation was still low, both in terms of trees around the settlement and height, walls and fences were still not effective at reducing noise. Based on the results of measurements of noise levels around Sultan Syarif Kasim II airport, it is known that the location of point 1 (Jl. Rawa Indah II) experienced the highest noise exposure. These results indicate that the location of point 1 should receive serious attention for the people who live around the airport, because the impact of airport noise has the potential to negatively affect the lives of residential communities. From the observations, it was also known that the level of noise attenuation was still low, both in terms of trees around the settlement and height, walls and fences were still not effective at reducing noise. From the results of the research that has been done, several mitigation strategies can be formulated to reduce noise levels around Sultan Syarif Kasim II airport. Planting plants in accordance with the needs of controlling or reducing noise in human settlements. Tree categories suitable for planting in residential areas around the airport are: shady trees that can be planted tightly or with lots of leaves that can grow to a height of about $4-15 \mathrm{~m}$ (such as acacia, mahogany, flamboyant, ironwood or banyan trees, bamboo or cypress)

Keywords: airplane noise; noise impact; barrier; control mitigation
\end{abstract}

Kebisingan adalah bunyi yang tidak diinginkan dari usaha atau kegiatan dalam tingkat dan waktu tertentu yang dapat menimbulkan gangguan kesehatan manusia dan kenyamanan lingkungan. Tingkat kebisingan berkaitan dengan ukuran energi bunyi yang dinyatakan dalam satuan decible disingkat $\mathrm{dB}$ (Kep.Men. LH No 48,1996). Seperti yang diungkapakan diatas bahwa kebisingan sebagai factor-faktor yang dapat menyebabkan gangguan kesehatan, diantaranya adalah gangguan pendengaran meliputi tekanan kebisingan, durasi pajanan dalam sehari dan lama bekerja, kerentanan individu, umur, gangguan atau penyakit lain, sifat lingkungan kebisingan, jarak telinga dengan sumber kebisingan dan posisi telinga terhadap sumber bunyi (Waskito, 2008). Banyak penelitian, mengungkapkan kebisingaan dapat mempengaruhi penurunan kemampuan mendengar dan kebisingan juga mempengaruhi sistem kardiovaskular pekerja dan mengarah ke hipertensi, sakit kepala, kelelahan, kegelisahan, dan kemarahan (Khajenasiri, 2016).

Tingkat kebisisngan atau suara yang ditimbulkan dari bunyi adalah gangguan bagi kehidupan manusia, biasanya suara kebisingan tersebut yang diciptakan mesin. (Firdaus dan Ahmad dalam Jariwala, 2017) menyatakan masalah lingkungan yang ditimbulkan dari polusi kebisingan yang bersumber dari bunyi 


\section{ZONA}

Jurnal Lingkungan

Volume 4, No 2, Oktober 2020, p. 91-106

ISSN : 2502-6496 (Print)

http://zona.pelantarpress.co.id

mesin terus berkembang dan meningkat menjadi bentuk pencemaran yang ada di mana-mana, namun tanpa disadari tidak hanya di negara-negara maju tetapi juga di negara-negara berkembang. Beberapa tahun terakhir telah melihat peningkatan kekuatan bukti yang menghubungkan paparan kebisingan lingkungan terhadap lingkungan khususnya kesehatan manusia (Clark, 2015). Pada tahun 2012, Organisasi Kesehatan Dunia (WHO) memperkirakan bahwa antara 1 dan 1,6 juta tahun hidup sehat (Penyandang Disabilitas) hilang setiap tahun karena paparan kebisingan lingkungan, diantaranya kebisingan mesin pesawat.

Kebisingan mesin pesawat merupakan perkembangan yang terkait lagsung kemajuan suatu daerah, psawat merupakan transportasi yang dibutuhkan untuk mempercepat hubungan antar masyarakat antar kota dan provinsi. Disamping lingkungan hidup masyarakat, aspek karyawan yang bekerja disekitar Bandara juga dapat berdampak negative pada lingkungan kerja. Karyawan sangat merasakan kuatnya suara bunyi mesin pesawat ketika mendarat dan lepas landas (Ramita dan laksmono, 2011). Dari beberapa hasil penelitian yang sudah dilakukan oleh peneleiti sebelumnya, ditemukan tingkat kebisingan tertinggi di kawasan Bandar Udara International Sultan Syarif Kasim II berada di landasan pacu selatan yaitu 88,63 dBA Untuk tingkat kebisingan terendah berada pada titik apron timur yaitu 77,72 dBA (Ferial et. al, 2016). Hasil penelitian ini juga didukung oleh hasil penelitian (Komang, et al, 2016) yang menyatakan tingkat kebisingan di perumahan sekitar Bandara Internasional Sultan Syarif Kasim II Pekanbaru keseluruhannya melebihi tingkat kebisingan yang diperbolehkan yaitu $55 \mathrm{dBA}$. Dari beberapa hasil penelitian ini terlihar adanya dampak negatif kebisingan yang dapat terjadi di lingkungan pemukiman sekitar bandara, begitu pula di sekitar Bandara Sultan Syarif Kasim II Pekanbaru.

Menurut penelitian (Dirk Schreckenberg at. al, 2010) paparan satu suara pertama menghasilkan reaksi gangguan psikologis seperti gangguan yang mengarah ke stres psikologis yang sekali lagi menyebabkan efek kesehatan fisik dan mental. Dalam kasus ekstrim, sensitivitas kebisingan sangat besar sehingga menyebabkan penderitanya mengisolasi diri dari lingkungan yang bising dan menarik diri dari masyarakat secara umum. Dalam kasus ini, penderita mungkin menganggap suara pelan sebagai suara keras dan sedang sebagai suara yang benar-benar tidak tertahankan. Dikenal sebagai hyperacusis, kondisi ini dapat berkembang dari paparan berlebihan hingga suara keras (Seth Morris; https://www.zyto.com/reduce-noise-pollution). Dari beberapa hasil penelitian yang disebutkan diatas, jelas bahwa kebisingan yang ditimbulkan dari bunyi mesin pesawat yang sangat kuat menimbulkan dampak terhadap lingkungan pemukiman di sekitar bandara. Dampak yang ditimbulkan oleh kebisingan ini cukup mengganggu dan dapat merugikan manusia dan lingkungan disekitar paparan, maka dari itu paparan kebisingan ini wajib di tanggulangin dengan benar agar tidak menimbulkan masalah dan kerugian bagi perusahaan maupun penduuduk sekitar kawasan bandara. Oleh karenanya faktor mitigasi pengendalian terhadap damapak negative terhadap lingkungan pemukiman menjadi hal yang sangat penting di kaji secara ilmiah. Dikarenakan perkembangan jumlah pesawat yang semakin intensif sehingga besar kemungkinan menciptakan gangguan terhadap kehidupan pemukinan masyarakat yang ada disekitar bandara, sudah selayaknya diperlukan mencari solusi sebagai antisiasi kemungkinan dampak dari gangguan kebisingan pesawat di bandara.

Bandara Sultan Syarif Kasim II (SSK II) Pekanbaru terletak di tengah kota Pekanbaru dan tepatnya di sekitar pemukiman masyarakat yang terus semakin berkembang. Keberadaan bandara di pekanbaru sudah berubah bukan hanya sekedar menyediakan tempat pelayanan pelanggan atau landasan pacu pesawat tapi saat ini angkutan pesawat menjadi sangat penting dan vital bagi kelangsungan perekonomian suatu daerah. Sejalan dengan itu, pemukiman masyarakat semakin padat di sekitar bandara, menjadikan lingkunagan sekitar bandara sangat rentan terhadap kebisingan yang ditimbulkan mesin pesawat, dianatranya rentan terhadap kerusakan pendengaran dalam bentuk pergeseran, ambang dengar temporer atau permanen. Oleh sebab itu (Chaeran, 2008) menyarankan perlu upaya pengendalian bising di lingkungan Bandara yang mencakup pengendalian untuk karyawan penerbangan dan juga untuk lingkungan sekitar Bandara.

\section{METODE PENELITIAN}

Penelitian ini akan dilaksanakan pada bulan September 2020. Tempat penelitian berada di Bandar Udara dan di sekitar Bandara Sultan Syarif Kasim II Pekanbaru. Titik pengambilan sampel kebisingan berada di Landasan Utara (Jl. Kaswari, Jl. Rawa Indah II, Jl. Rawa Indah III Kel. Sidomulyo Timur Kec. Marpoyan Damai) dan Landasan Selatan (Jl. Kayu Manis, Jl. Pahlawan Kerja Gg. Dame dan Jl. Nur Asiyah Kel. Maharatu Kec. Marpoyan Damai). Adapun alat yang digunakan pada penelitian ini adalah satu buah peta rupa bumi dan peta digital Bandar Udara Sultan Syarif Kasim II Pekanbaru, Sound Level Meter (SLM), tripod, stopwatch, Aplikasi Surfer 11, perangkat komputer, handphone dan alat tulis. Jenis data yang digunakan dalam penelitian ini adalah data kuantitatif. Sumber data pada penelitian ini adalah: Data primer diperoleh dari hasil pengukutan tingkat kebisingan selama jam operasional bandara yaitu pukul 
06.00 WIB - 22.00 WIB dan data metereologi yang meliputi data kecepatan angin, arah angin, dan suhu udara dan data sekunder diperoleh dari berbagai Instansi terkait, BPS (Badan Pusat Statistik) Kota Pekanbaru, Pemuka Masyarakat dan berbagai literatur atau kajian terkait yang mendukung penelitian ini.

Teknik observasi yang dilakukan pada penelitian ini yaitu melakukan pengamatan secara langsung pada lokasi penelitian dengan melihat kondisi lokasi dan kesesuaian lokasi yang menjadi titik sampling penelitian (batas landasan tingkat kebisingan di Bandar Udara Sultan Syarif Kasim II). Dalam observasi juga dilakukan dokumentasi dalam bentuk foto, mengumpulkan informasi dari masyarakat secara lisan mengenai lokasi dan obyek penelitian.Data yang diperoleh dalam penelitian ini di analisis secara kuantitatif dan kualitatif. Pengolahan data dilakukan menggunakan program Microsoft Office Excel. Untuk mengukur tingkat kebisingan Bandar Udara Sultan Syarif Kasim II Pekanbaru dilakukan pengukuran dengan menggunakan alat Sound Level Meter (SLM) di landasan yang sudah ditentukan. Pengukuran dilakukan pada hari kerja dan hari libur dengan metode pengambilan duplow.

\section{HASIL DAN PEMBAHASAN}

\section{Gambaran Umum Lokasi Pengendalian}

Bandar Udara Internasional Sultan Syarif Kasim II (SSK II) secara administrasi terletak di Maharatu Kecamatan Marpoyan Damai, Kota Pekanbaru, Provinsi Riau dan berada sekitar $10 \mathrm{~km}$ ke arah selatan pusat kota dan pada koordinat 00 27' 27,13" LU - 101 26'36,55” BT dengan ketinggian 101 feet diatas permukaan laut rata - rata. Bandar Udara ini termasuk salah satu bandar udara yang dikelola oleh PT Angkasa Pura II. Bandara Internasional SSK II Pekanbaru adalah bandara yang dikelola perusahaan negara yaitu PT. Angkasa Pura II. Sebagai pengelola bandara, perusahaan sudah mempersiapkan berbagai fasilitas yang dibutuhkan bagi kelancaran penerbangan yang akan berangkat dan datang dari berbagai kota di Indonesia dan juga melayani penerbangan dari dan luar negeri.

Dalam penyediaan sarana pelayanan memiliki landasan pacu (runway) yang berdimensi $2.240 \mathrm{~m} \mathrm{x}$ $45 \mathrm{~m}$, arah landasan pacu berada diposisi utara dan selatan. Bandar Udara Sultan Syarif Kasim II Pekanbaru melayani penerbangan domestik, internasional dan militer. Untuk internasional hanya melayani penerbangan ke Singapura dan Malaysia. Jumlah penumpang di Bandara Sultan Syarif Kasim II ini meningkat tiap tahunnya dan pada tahun 2018 menurut catatan Badan Pusat Statistik dalam publikasi berjudul Statistik Angkutan Udara Provinsi Riau 2018 tercatat jumlah penumpang yang datang 2,05 Juta penumpang dan untuk keberangkatan 2,06 Juta penumpang.

\section{Analisa Tingkat Kebisingan di Pemukiman Sekitar Bandara SSK II Pekanbaru}

Tingkat Tekanan Suara (LP)

Pengukuran tingkat tekanan suara dilakukan pada hari libur (Minggu) dan hari kerja (Senin), yaitu dimulai pada tanggal 01 November, 02 November, 08 November, dan 09 November 2020 yang dilakukan dikawasan pemukiman sekitar Bandar Udara Sultan Syarif Kasim II Pekanbaru yang tersebar di 6 titik pengukuran dimama pengukuran tingkat tekanan suara ini dilakukan secara duplo. Pada saat pengukuran kondisi meteorologi yaitu temperatur $24,8^{\circ} \mathrm{C}-35,7^{\circ} \mathrm{C}$, Kelembaban $48,7-89,6 \%$, kecepatan angin 0,1-2,2 $\mathrm{m} / \mathrm{s}$ dan arah angin dominan dari tiimur dan selatan. Data tingkat tekanan suara (Lp) diukur setiap 5 detik selama 10 menit pada rentang waktu yang telah ditentukan sehingga data yang dihasilkan untuk satu kali pengukuran dan satu titik pengukuran adalah 120 data. Berikut ini adalah data pengukuran yang dihasilkan pada salah satu waktu pengukuran yaitu hari Minggu yang pertama.

Tabel 1. Rekapitulasi Nilai Lp Hasil Pengukuran di kawasan pemukiman sekitar bandara Hari Minggu

\begin{tabular}{|c|c|c|c|c|c|}
\hline \multirow{2}{*}{$\begin{array}{l}\text { Titik } \\
\text { Pengukuran }\end{array}$} & \multicolumn{5}{|c|}{ Nilai Lp (dBA) } \\
\hline & & L 1 & L 2 & L 3 & $\mathrm{~L} 4$ \\
\hline \multirow[t]{2}{*}{1 (j1 Kaswari) } & Min & 35,4 & 44,7 & 49,3 & 43,4 \\
\hline & Max & 70,8 & 95,8 & 88,7 & 73,4 \\
\hline \multirow{2}{*}{$\begin{array}{l}2 \quad \text { (j1 Rawa } \\
\text { Indah II) }\end{array}$} & Min & 31,3 & 37,0 & 35,8 & 43,9 \\
\hline & Max & 50,4 & 82,9 & 95,8 & 112,3 \\
\hline \multirow{2}{*}{$\begin{array}{l}3 \text { (j1 Rawa } \\
\text { Indah III) }\end{array}$} & Min & 37,3 & 38,4 & 50,4 & 54,6 \\
\hline & Max & 71,9 & 67,6 & 78,9 & 90,1 \\
\hline \multirow{2}{*}{$\begin{array}{lrl}4 & \text { (j1 } & \text { Kayu } \\
\text { Manis) } & \end{array}$} & Min & 36,1 & 44,7 & 37,8 & 46,2 \\
\hline & Max & 73,7 & 99,4 & 102,6 & 65,2 \\
\hline 5 (j1 Pahlawan & Min & 41,4 & 41,4 & 43,5 & 47,5 \\
\hline
\end{tabular}




\begin{tabular}{|c|c|c|c|c|c|c|}
\hline \multicolumn{2}{|c|}{ Kerja gg Pala) } & $\operatorname{Max}$ & 89,4 & 76,6 & 94,6 & 75,2 \\
\hline \multirow{2}{*}{$\begin{array}{lr}6 \quad(j 1 \\
\text { Aisyah) }\end{array}$} & \multirow[t]{2}{*}{ Nur } & Min & 43,4 & 45,7 & 35,6 & 42,9 \\
\hline & & $\operatorname{Max}$ & 74,5 & 93,0 & 73,7 & 71,4 \\
\hline
\end{tabular}

Nilai Leq dan LS

Nilai Leq yang diperoleh pada waktu pengukuran adalah pada hari Minggu yang pertama $(41,67$ $89,23)$ dBA, pada hari Minggu yang kedua $(47,13-76,46)$ dBA, pada hari Senin yang pertama $(49,56-$ $87,47) \mathrm{dBA}$, dan pada hari Senin yang kedua $(50,89-92,18) \mathrm{dBA}$, sedangkan hasil pengolahan data dapat dilihat pada Tabel berikut.

Tabel 2. Hasil Perhitungan Tingkat Kebisingan pada hari Minggu yang pertama

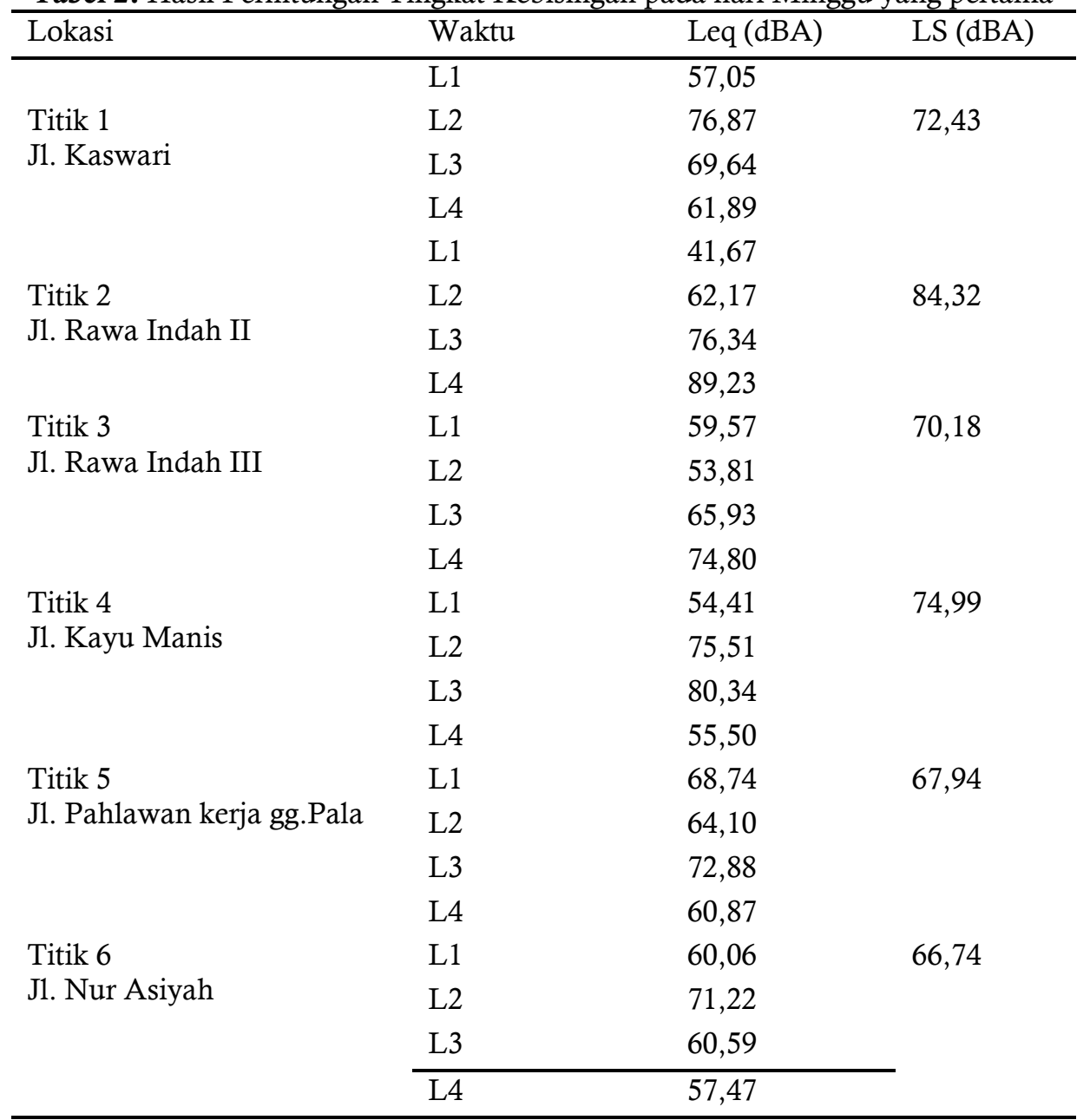

Dari tabel 2 diketahui bahwa tingkat kebisingan Leq yang dihasilkan oleh pesawat terbang di bandara dari 6 (enam) titik yang diteliti pada periode weekkday pertama menunjukkan semua lokasi penelitian yang terpapar kebisingan mengalami tingkat kebisingan diatas nilai baku mutu yang diperbolehkan Keputusan Menteri Negara Lingkungan Hidup No. 48 Tahun 1996 hanya sebesar 55 dB(A). Dengan perincian, nilai kebisingan yang tertinggi terdapat pada titik 2 (dua) yakni 84,32 dB(A), sedangkan yang terendah pada titik 6 (enam) yakni 66,74 $\mathrm{dB}(\mathrm{A})$. Intensitas kebisingan yang sangat dirasakan oleh masyarakat yang tinggal di sekitar titik 2 (dua) tentu dampak kebisingan menjadi faktor penting dicarikan solusi untuk mengantisipasi dampak resiko kebisingan terhadap kehidupan masyarakat di sekitar Jl. Rawa Indah II (titik 2) tersebut. 
Tabel 3. Hasil Perhitungan Tingkat Kebisingan pada hari Minggu yang kedua

\begin{tabular}{|c|c|c|c|}
\hline Lokasi & Waktu & Leq (dBA) & $\mathrm{LS}(\mathrm{dBA})$ \\
\hline \multirow{4}{*}{$\begin{array}{l}\text { Titik } 1 \\
\text { Jl. Kaswari }\end{array}$} & L1 & 71,67 & \multirow{4}{*}{71,46} \\
\hline & L2 & 73,11 & \\
\hline & L3 & 71,79 & \\
\hline & L4 & 68,12 & \\
\hline \multirow{2}{*}{$\begin{array}{l}\text { Titik } 2 \\
\text { Jl. Rawa Indah II }\end{array}$} & L1 & 47,13 & \multirow[t]{2}{*}{67,01} \\
\hline & $\mathrm{L} 2$ & 61,30 & \\
\hline & L3 & 59,21 & \\
\hline \multirow{6}{*}{$\begin{array}{l}\text { Titik } 3 \\
\text { Jl. Rawa Indah III }\end{array}$} & $\mathrm{L} 4$ & 71,52 & \multirow{6}{*}{72,42} \\
\hline & L1 & 65,16 & \\
\hline & L2 & 63,15 & \\
\hline & L3 & 76,46 & \\
\hline & L4 & 74,03 & \\
\hline & L1 & 58,47 & \\
\hline \multirow{2}{*}{$\begin{array}{l}\text { Titik } 4 \\
\text { J1. Kayu Manis }\end{array}$} & L2 & 59,60 & \multirow[t]{2}{*}{68,87} \\
\hline & L3 & 75,85 & \\
\hline \multirow{6}{*}{$\begin{array}{l}\text { Titik } 5 \\
\text { Jl. Pahlawan kerja gg.Pala }\end{array}$} & L4 & 54,23 & \multirow{5}{*}{64,96} \\
\hline & L1 & 60,87 & \\
\hline & L2 & 66,17 & \\
\hline & L3 & 68,25 & \\
\hline & L4 & 60,56 & \\
\hline & L1 & 58,46 & \multirow{3}{*}{63,63} \\
\hline \multirow{3}{*}{$\begin{array}{l}\text { Titik } 6 \\
\text { Jl. Nur Asiyah }\end{array}$} & L2 & 63,61 & \\
\hline & L3 & 67,81 & \\
\hline & L4 & 60,18 & \\
\hline
\end{tabular}

Dari peneltian periode penelitian weekend ke-2 ditemukan lokasi penelitian yang paling terdampak oleh tingkat kebisingan adalah lokasi titik 3 (tiga) yang mengalami tingkat kebisingan yang paling tinggi dari 6 lokasi penellitian. Tingkat kebisingan yang paling rendah dari 6 lokasi penelitian adalah titik 6 (Jl. Nur Asiyah). Jika dibandingkan dengan nilai baku mutu, maka dapat disimpulkan tingkat kebisingan semua titik atau lokasi penelitian berada diatas $55 \mathrm{~dB}(\mathrm{~A})$.

Tabel 4. Hasil Perhitungan Tingkat Kebisingan pada hari Senin yang pertama

\begin{tabular}{llll}
\hline Lokasi & Waktu & Leq (dBA) & LS (dBA) \\
\hline \multirow{2}{*}{ Titik 1 } & L1 & 63,50 & \\
J1. Kaswari & L2 & 84,37 & 80,40 \\
& L3 & 56,60 & \\
Titik 2 & L4 & 78,80 & \\
J1. Rawa Indah II & L1 & 70,63 & \\
& L2 & 79,63 & 74,91 \\
& L3 & 53,98 & \\
Titik 3 & L4 & 49,56 & \\
J1. Rawa Indah III & L1 & 76,58 & \\
& L2 & 72,12 & 71,79 \\
& L3 & 62,86 & \\
Titik 4 & L4 & 65,57 & \\
J1. Kayu Manis & L1 & 58,17 & \\
\hline
\end{tabular}




\begin{tabular}{llll}
\hline & L3 & 67,58 & \\
& L4 & 66,28 & \\
& L1 & 79,53 & \\
Titik 5 & L2 & 87,47 & \\
J1. Pahlawan kerja gg.Pala & & & \\
& L3 & 66,32 & \\
& L4 & 57,12 & \\
Titik 6 & L1 & 57,01 & \\
J1. Nur Asiyah & L2 & 69,11 & \\
& L3 & 72,15 & \\
\hline & L4 & 60,15 &
\end{tabular}

Berdasarkan tabel diatas menunjukkan bahwa intensitas kebisingan maksimum yang dihasilkan oleh kebisingan pewasat terbang yang melewati pemukiman masyarakat dari 6 tiitk atau lokasi penelitian adalah titik 4 (empat) yakni sebesar 82,19 $\mathrm{dB}(\mathrm{A})$ dan tingkat kebisingan yang paling rendah adalah titik 6 yakni $67,81 \mathrm{~dB}(\mathrm{~A})$. Jika dibandingkan dengan ambang batas kebisingan yang dapat diterima menurut Keputusan Menteri Negara Lingkungan Hidup No. 48 Tahun 1996 hanya sebesar 55 dB(A), maka daapat disimpulkan bahwa keenam lokasi titik penelitian memiliki nilai tingkat kebisingan di atas baku mutu yang diperbolehkan, artinya semua lokasi ini terdampak oleh kebisingan pesawat terbang yang melewati kehidupan pemukiman.

Tabel 5. Hasil Perhitungan Tingkat Kebisingan pada hari Senin yang kedua

\begin{tabular}{|c|c|c|c|}
\hline Lokasi & Waktu & Leq (dBA) & $\mathrm{LS}(\mathrm{dBA})$ \\
\hline \multirow{4}{*}{$\begin{array}{l}\text { Titik } 1 \\
\text { J1. Kaswari }\end{array}$} & L1 & 58,50 & \multirow{4}{*}{83,56} \\
\hline & $\overline{\mathrm{L} 2}$ & 64,32 & \\
\hline & $\overline{\mathrm{L} 3}$ & 90,81 & \\
\hline & $\overline{\mathrm{L} 4}$ & 55,42 & \\
\hline \multirow{4}{*}{$\begin{array}{l}\text { Titik } 2 \\
\text { Jl. Rawa Indah II }\end{array}$} & L1 & 92,18 & \multirow{4}{*}{84,95} \\
\hline & $\overline{\mathrm{L} 2}$ & 70,16 & \\
\hline & $\overline{\mathrm{L} 3}$ & 51,18 & \\
\hline & $\overline{\mathrm{L} 4}$ & 50,89 & \\
\hline \multirow{5}{*}{$\begin{array}{l}\text { Titik } 3 \\
\text { Jl. Rawa Indah III }\end{array}$} & L1 & 74,28 & \multirow{3}{*}{77,80} \\
\hline & $\overline{\mathrm{L} 2}$ & 82,27 & \\
\hline & $\overline{\mathrm{L} 3}$ & 66,16 & \\
\hline & L4 & 67,24 & \\
\hline & L1 & 54,37 & \multirow{4}{*}{60,84} \\
\hline \multirow{3}{*}{$\begin{array}{l}\text { Titik } 4 \\
\text { Jl. Kayu Manis }\end{array}$} & $\overline{\mathrm{L} 2}$ & 56,77 & \\
\hline & $\overline{\mathrm{L} 3}$ & 66,68 & \\
\hline & $\overline{\mathrm{L} 4}$ & 56,54 & \\
\hline \multirow{4}{*}{$\begin{array}{l}\text { Titik } 5 \\
\text { Jl. Pahlawan kerja gg.Pala }\end{array}$} & L1 & 56,54 & \multirow{4}{*}{72,46} \\
\hline & L2 & 58,43 & \\
\hline & $\overline{\mathrm{L} 3}$ & 79,33 & \\
\hline & $\overline{\mathrm{L} 4}$ & 66,06 & \\
\hline \multirow{4}{*}{$\begin{array}{l}\text { Titik } 6 \\
\text { Jl. Nur Asiyah }\end{array}$} & L1 & 88,82 & \multirow{4}{*}{81,57} \\
\hline & $\overline{\mathrm{L} 2}$ & 61,13 & \\
\hline & $\overline{\mathrm{L} 3}$ & 54,06 & \\
\hline & $\overline{\mathrm{L} 4}$ & 57,20 & \\
\hline
\end{tabular}

Dari penelitian pada hari Senin yang kedua, lokasi penelitian yang paling terpapar atau tingkat intensitas kebisingan yang tertinggi berada pada titik 2 (dua) yakni sebesar $84,95 \mathrm{~dB}(\mathrm{~A})$, dan nilai kebisingan yang terendah berada pada lokasi titik 4 (empat) yakni 60,84 dB(A). Secara keseluruhan, sesungguhnya tingkat kebisingan pada ke 6 lokasi peneliltian pada periode penelitian weekday ke-2 


\section{ZONA}

Jurnal Lingkungan

ISSN : 2502-6496 (Print)

Volume 4, No 2, Oktober 2020, p. 91-106 http://zona.pelantarpress.co.id

menunjukkan angka kebisingan di atas baku mutu yang diperbolehkan oleh Kep. Men. LH No. 48 Tahun 1996 hanya sebesar $55 \mathrm{~dB}(\mathrm{~A})$.

Tingkat Kebisingan Berdasarkan Lokasi Pengukuran

Tabel 6. Peringkat Kebisingan Berdasarkan Lokasi Pengukuran

\begin{tabular}{|c|c|c|c|}
\hline NO. & Lokasi Penelitian & $\begin{array}{l}\text { Tingkat Kebisingan } \\
\text { (Rata-Rata) }\end{array}$ & $\begin{array}{l}\text { Peringkat Kebisingan (Lokasi } \\
\text { Terdampak) }\end{array}$ \\
\hline 1. & T1 (J1. Rawa Indah II) & $77,31 \mathrm{~dB}(\mathrm{~A})$ & 2 \\
\hline 2. & T2 (J1. Kaswari) & $77,80 \mathrm{~dB}(\mathrm{~A})$ & 1 \\
\hline 3. & T3 (J1. Rawa Indah III) & $73,05 \mathrm{~dB}(\mathrm{~A})$ & 3 \\
\hline 4. & T4 (J1. Kayu Manis) & $71,72 \mathrm{~dB}(\mathrm{~A})$ & 5 \\
\hline 5. & T5 (J1. Pahlawan kerja gg.Pala) & $72,05 \mathrm{~dB}(\mathrm{~A})$ & 4 \\
\hline 6. & T6 (J1. Nur Asiyah) & $69,94 \mathrm{~dB}(\mathrm{~A})$ & 6 \\
\hline
\end{tabular}

Berdasarkan tabel diatas diketahui bahwa lokasi peneltian yang paling terdampak akibat kebisingan pesawat di sekitar bandara adalah Rumah Kopi yakni 77,31 dB(A) sedangkan tingkat kebisingan yang paling rendah berada pada lokasi Kosan Kosong yakni 69,94 dB(A) Ini berarti bahwa masyarakat yang bermukim di lokasi Rumah Kopi sangat merasakan dampak kebisingan terhadap kehidupan sehari hari. Daerah ini harus menjadi fokus usaha pengendalian yang penting dilakukan baik oleh pemerintah maupun masyarakat itu sendiri, karena pengendalian dampak kebisingan dibutuhkan sebagai antisipasi terhadap kemungkinan dampak yang dihadapi dari tingkat kebisingan yang tinggi.

\section{Pemetaan Kebisingan}

Pemetaan tingkat kebisingan dilakukan dengan menggunakan program Surfer 11, sehingga diperoleh gambar berupa garis-garis kontur yang menghubungkan titik-titik sampling dalam bentuk isodesibel di kawasan Pemukiman Bandara Internasional Sultan Syarif Kasim II Pekanbaru. Gambar isodesibel hasil pengukuran LS dapat dilihat pada gambar 1 sampai gambar 4

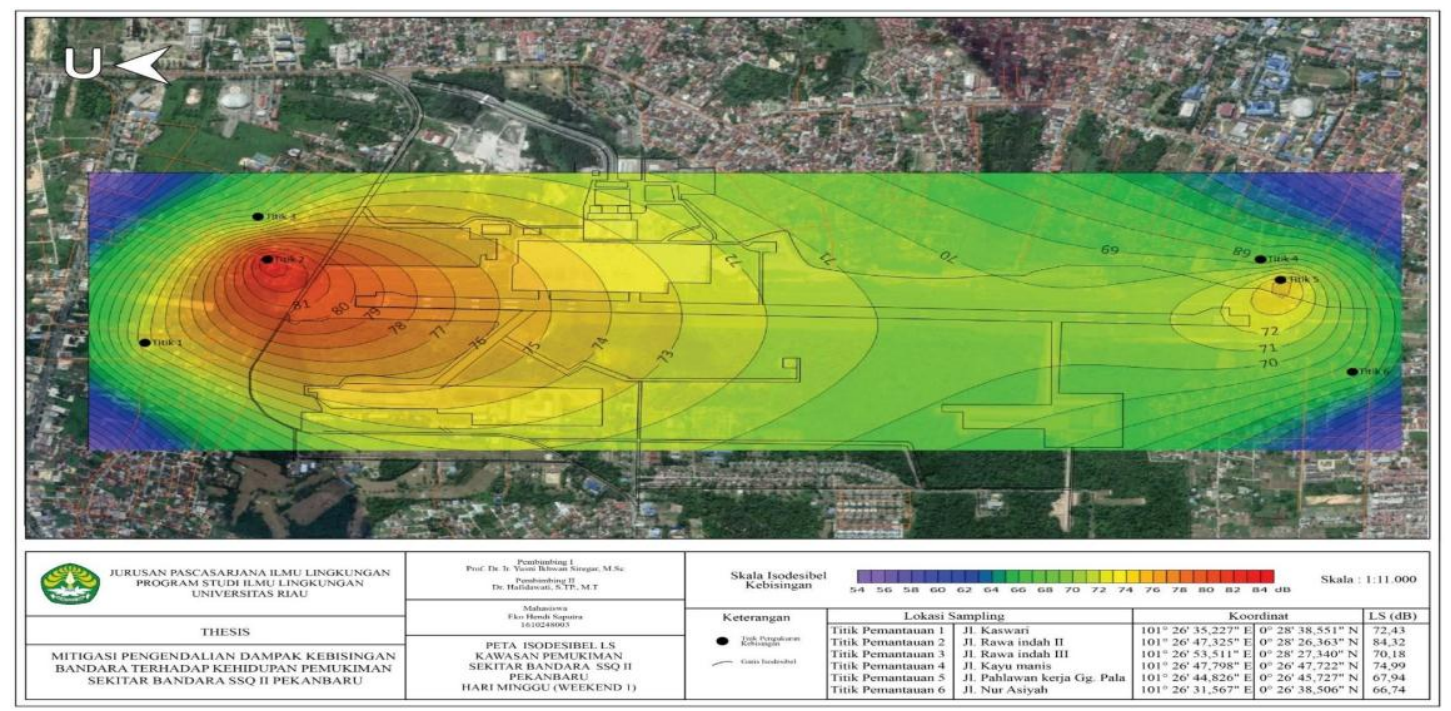

Gambar 1. Peta Isodibel Kebisingan Pada Pengukuran Hari Minggu Yang Pertama 

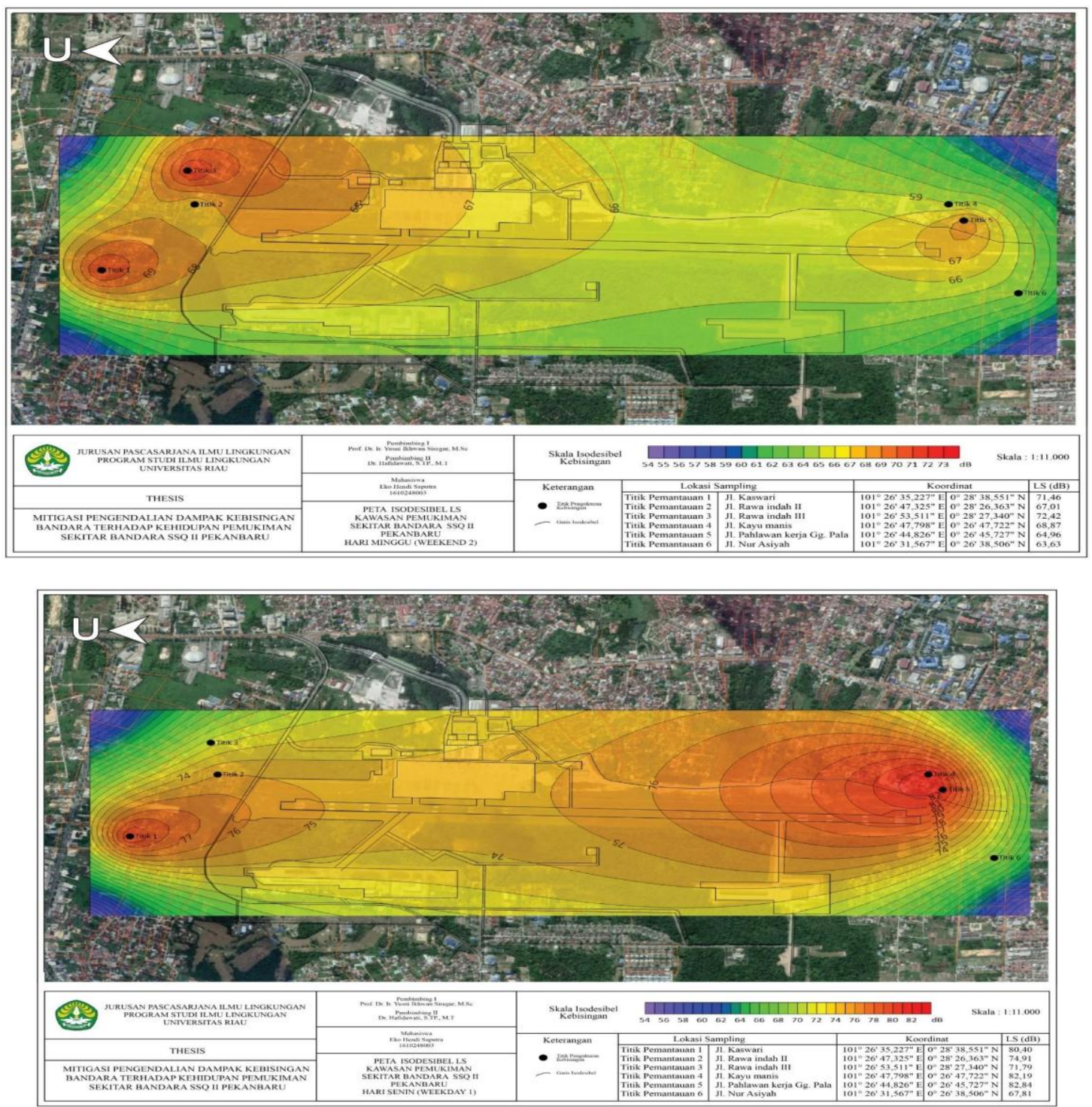

Gambar 2. Peta Isodibel Kebisingan Pada Pengukuran Hari Minggu Yang Kedua
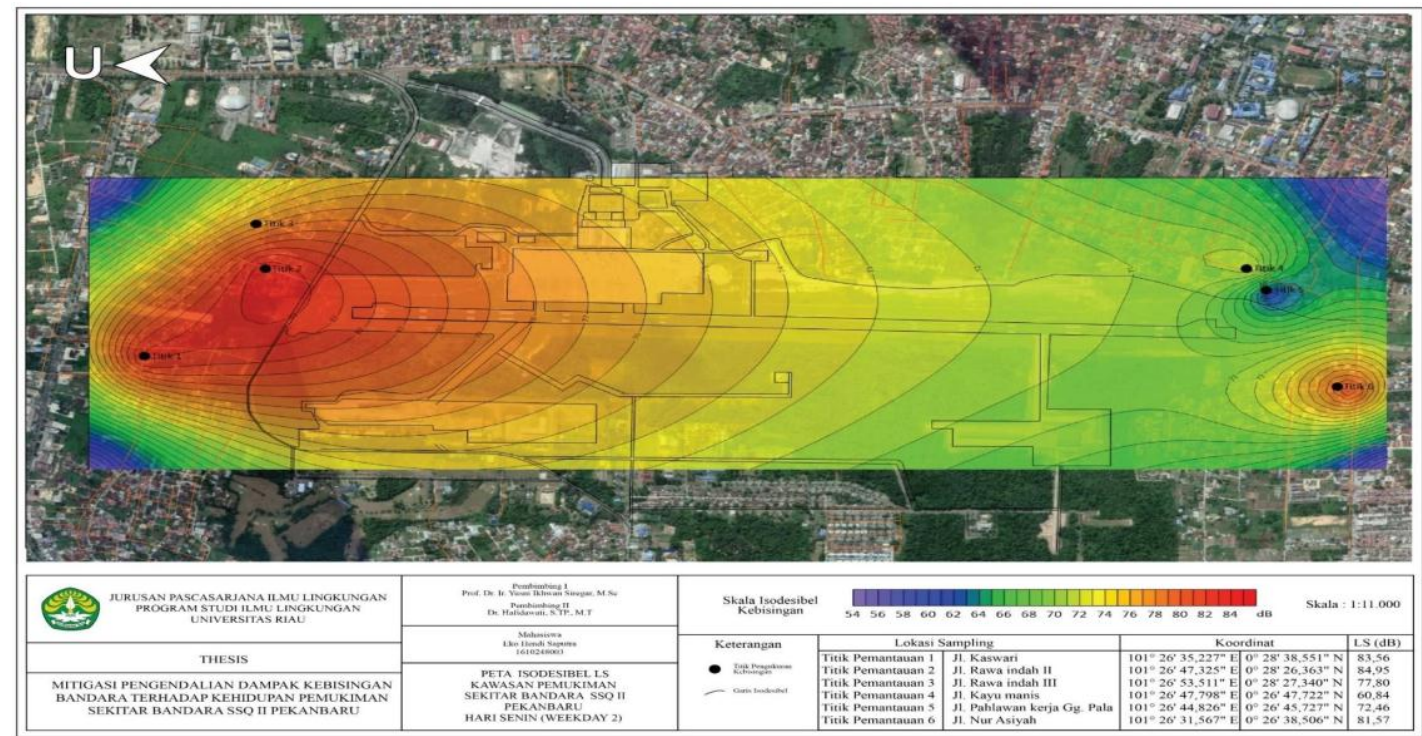

Gambar 3. Peta Isodibel Kebisingan Pada Pengukuran Hari Senin Yang Pertama 


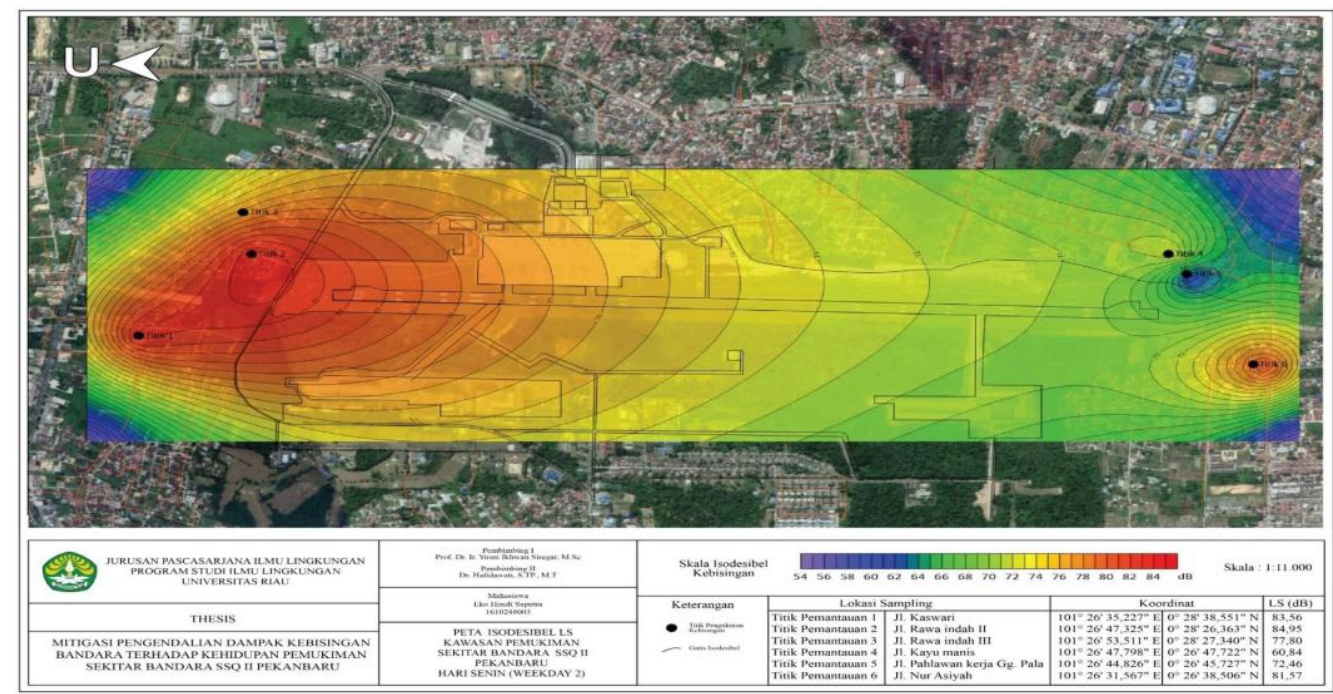

Gambar 4. Peta Isodibel Kebisingan pada pengukuran Hari Senin yang kedua

Analisis Pola Penyebaran Kebisingan

Hasil analisis pola penyebaran tingkat kebisingan di kawasan pemukiman sekitar Bandara SSK II Pekanbaru adalah sebagai berikut:

1. Gambar 1 menunjukkan bahwa hasil tingkat kebisingan LS yang paling tinggi terletak pada Titik 2 (dua) Jl. Rawa Indah II, dimana titik ini berada dikawasan yang dekat dengan landasan pacu Utara pesawat. Tingkat kebisingan pada area ini adalah 84,32 dBA. Tingkat kebisingan pada Titik lainnya yang berada di dekat landasan pacu Utara bandara cukup tinggi, yaitu 72,43 dBA pada Titik 1 (satu) dan 70,18 dBA pada Titik 3 (Tiga). Tingginya tingkat kebisingan di kawasan pemukiman ini disebabkan oleh aktifitas penerbangan pesawat udara pada hari Minggu yang pertama lebih dominan dari sisi landasan pacu Utara.

2. Gambar 2 menunjukkan bahwa tingkat kebisingan LS yang cenderung tinggi adalah di area sekitar landasan pacu Utara bandara. Pada area ini tingkat kebisingan tertinggi berada di Titik 1 (satu) dan Titik 3 (tiga) dengan tingkat kebisingan masing-masing adalah 71,46 dBA dan 72,42 dBA. Dapat dilihat bahwa nilai tingkat kebisingan tertinggi berada pada Titik 3 (tiga) yaitu berada di Jl. Rawa Indah III.

3. Gambar 3 menunjukkan bahwa tingkat kebisingan tertinggi berada di area Selatan landasan pacu bandara yaitu pada Titik 5 (lima) dengan tingkat kebisingan yang dihasilkan 82,84 dBA. Pada pengukuran hari Senin yang pertama ini kebisingan yang dihasilkan di area Selatan dan Utara landasan pacu cenderung tinggi, hal ini dikarenakan jumlah pesawat yang menggunakan landasan pacu bandara sebagai jalur pesawat landing dan take off bertambah karena pesawat tempur milik TNI AU juga beroperasi.

4. Gambar 4 menunjukkan bahwa hasil tingkat kebisingan LS yang paling tinggi berada pada Titik 2 (dua) sebesar 84,95 dBA dimana titik ini sangat dekat dengan batas landasan pacu Utara. Sebaran kebisingan yang ditunjukkan pada peta isodesibel ini menunjukkan bahwa titik-titik pengukuran yang berposisi di sekitar landasan pacu Utara cenderung tinggi. Tingkat kebisingan yang tinggi pada area ini dipicu faktor penambahan aktifitas penerbangan dari TNI AU.

Dari gambar tersebut dapat disimpulkan bahwa pola penyebaran kebisingan yang cenderung tinggi berada pada area pemukiman didekat landasan pacu Utara bandara. Aktifitas penerbangan yang berlangsung merupakan sumber utama kebisingan terutama pada jalur lintasan pesawat terbang baik yang akan landing maupun take off. Dari 4 (Empat) hari melakukan penelitian dimana waktu pengukuran dilakukan pada hari libur dan hari kerja, maka dapat diperoleh hasil pengukuran tingkat bising tertinggi terjadi pada pengukuran hari ke-4 yaitu hari kerja (hari Senin yang kedua).

\section{Evaluasi Tingkat Kebisingan}

Berdasarkan Keputusan Menteri Negara Lingkungan Hidup No. KEP- 48/MENLH/11/1996 Tentang Baku Tingkat Kebisingan, baku mutu tingkat kebisingan yang sesuai dengan peruntukan kawasan sebagai fungsi perumahan / pemukiman adalah sebesar $55 \mathrm{dBA}$ dengan toleransi sebesar $+3 \mathrm{dBA}$. Hasil perbandingan LS dengan baku mutu tingkat kebisingan dapat dilihat pada tabel berikut. 
Tabel 7. Perbandingan LS dengan Baku Mutu Tingkat Kebisingan pada Hari Senin Pengukuran

\begin{tabular}{|c|c|c|c|c|c|c|}
\hline \multirow[t]{2}{*}{ Titik Pengukuran } & \multirow{2}{*}{$\begin{array}{l}\text { LS } \\
\text { (dBA) }\end{array}$} & \multicolumn{3}{|c|}{ KepMenLH No. 48/MenLH/1996 } & \multirow{2}{*}{$\begin{array}{l}\text { Selisih } \\
\text { (dBA) }\end{array}$} & \multirow[b]{2}{*}{ Ket } \\
\hline & & $\begin{array}{l}\text { Baku Mutu } \\
\text { (dBA) }\end{array}$ & $\begin{array}{l}\text { Toleransi } \\
\text { (dBA) }\end{array}$ & $\begin{array}{l}\text { Jumlah } \\
\text { (dBA) }\end{array}$ & & \\
\hline Titik 1 & 83,56 & 55 & +3 & 58 & 25,56 & Melebihi \\
\hline \multicolumn{7}{|l|}{ J1. Kaswari } \\
\hline Titik 2 & 84,95 & 55 & +3 & 58 & 26,95 & Melebihi \\
\hline
\end{tabular}

J1.Rawa Indah II

Titik 3

$\begin{array}{lcccccc}\text { J1. Rawa Indah } & 77,80 & 55 & +3 & 58 & 19,8 & \text { Melebihi } \\ \text { III } & & & & & & \\ \text { Titik } 4 \quad 60,84 & 55 & +3 & 58 & 2,84 & \text { Melebihi } \\ \begin{array}{l}\text { J1. Kayu Manis } \\ \text { Titik } 5\end{array} & 72,46 & 55 & +3 & 58 & 14,46 & \text { Melebihi } \\ \text { J1. Pahlawan } & & & & & & \\ \text { Kerja Gg.Pala }\end{array}$

\begin{tabular}{lllllll}
\hline Titik 6 & 81,57 & 55 & +3 & 58 & 23,57 & Melebihi \\
J1. Nur Asiyah & & & & & & \\
\hline
\end{tabular}

Setelah melihat hasil perbandingan nilai LS dengan baku mutu tingkat kebisingan yang sesuai dengan peruntukan kawasan sebagai fungsi perumahan/pemukiman dapat diketahui bahwa seluruh perumahan yang berada dekat dengan kawasan Bandara Internasional Sultan Syarif Kasim II Pekanbaru terpapar kebisingan yang telah melebihi baku tingkat kebisingan yang telah ditetapkan. Hal ini disebabkan tingginya aktivitas penerbangan yang terjadi di bandara tersebut.

\section{Mitigasi Kebisingan}

Mitigasi kebisingan atau pengendalian kebisingan merupakan suatu usaha yang dilakukan untuk mereduksi kebisingan yang terjadi, agar tingkat bising yang dihasilkan oleh sumber bising tidak mengakibatkan terjadinya penurunan kesehatan manusia. Pengendalian kebisingan di area perumahan disekitar bandara dapat dilakukan dengan menghalangi jalan rambatan suara bising tersebut. Salah satunya adalah pembuatan Noise Barrier. Noise Barrier (Soundwall, Tanggul suara, penghalang suara, atau penghalang akustik) adalah struktur eksterior yang dirancang untuk meredam polusi suara (bising) (Aggasy, 2012). Noise Barrier yang sering digunakan terdapat 2 macam, yaitu Noise Barrier Alami dan Noise Barrier Buatan. Noise Barrier Alami adalah penghalang kebisingan yang tersusun atas tanaman-tanaman. Tanaman yang digunakan untuk penghalang kebisingan harus memilki kerimbunan dan kerapatan daun yang cukup merata guna menyerap bunyi. Sedangkan noise barrier buatan ialah penghalang bunyi yang sengaja dibuat manusia dengan bahan seperti beton, kaca, kayu, logam atau besi (Aggasy, 2012).

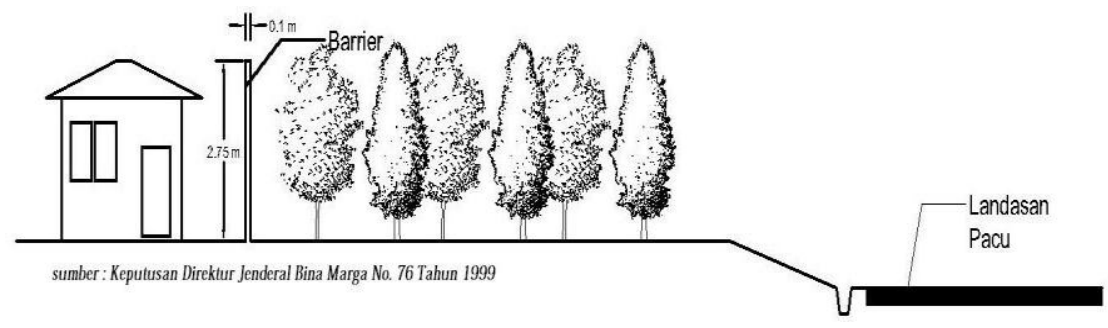

Gambar 5. Noise Barrier yang disarankan 
Untuk mengendalikan dampak tingakt kebisingan atau meredam kebisingan dapat dilakukan dengan menggunakan tanaman pohon pelindung. Penanaman pohon rimbun dengan jarak tanam tertentu dan sesuai dengan batas ketinggian pada lingkungan bandar udara dapat berfungsi sebagai zona penyangga. Berdasarkan Keputusan Menteri Perhubungan Nomor KM. 77 Tahun 1998, dijelaskan bahwa ada beberapa jenis tanaman atau pohon yang dapat berfungsi meredam kebisingan, diantaranya casia siame (johar), hibiscus tiliaceus (waru), angsana, tanjung, kiara payung, dan glondongan. Untuk mengetahui keadaan peredam kebisingan yang berlangsung pada saat penelitian pengukuran dilakukan dapat dilihat pada tabel berikut ini.

Tabel 8. Kondisi Peredam Bising Barrier Alami di Lokasi Pengukuran

\begin{tabular}{lllll}
\hline & Tanaman & & Jenis & Tingkat \\
Titik Pengukuran & Kerimbunan & Ketinggian Pohon & & Peredam \\
Titik 1 Jl. Kaswari & Jarang & $<3 \mathrm{~m}$ & Variasi & Rendah \\
& & & & \\
Titik 2 J1.Rawa & Jarang & $>3 \mathrm{~m}$ & Variasi & Rendah \\
Indah II & & & & \\
Titik 3 & Jarang & $>3 \mathrm{~m}$ & Variasi & Sedang \\
J1. Rawa Indah III & & & & \\
Titik 4 & Jarang & $<3 \mathrm{~m}$ & Variasi & Rendah \\
J1. Kayu Manis & & & & \\
Titik 5 & & & & \\
J1. Pahlawan Kerja & Jarang & $<3 \mathrm{~m}$ & Variasi & Rendah \\
Gg.Pala & & & & \\
\hline Titik 6 & Jarang & $<3 \mathrm{~m}$ & Variasi & Rendah \\
J1. Nur Asiyah & & & & \\
\hline
\end{tabular}

Dari hasl pengamatan lapangan di 6 titik pengukuran, diketahui bahwa Lokasi titik I (Jl. Kaswari) merupakan pemukiman yang memililki tanaman pepohonan yang bervariasi dengan kerimbunan jarang atau melebiihi 5 meter. Tinggi pohon rata-rata kurang dari $3 \mathrm{~m}$. Secara keseluruhan terlihat bahwa bahan bangunan yang digunakan permukiman dan sekolah adalah lembar aluminium untuk pemukiman dan batu bata tembok. Dari hasil pengamatan di Titik 2 (Jl Rawa Indah II) ditemukan secara keseluruhan tanaman pohon tanaman sebagai peredam kebisingan masih menunjukkan tingkat peredam yang rendah, terlihat dari pekarangan permukiman yang ditanami bermacam-macam jenis pohon dengan kerimbunan jarang dan tinggi pohon diatas 3 meter namun masih diawah 5 meter.

Dari hasil pengamatan lapangan pada titik 3 (J1 Rawa Indah III) ditemukan seacra umum tanaman peredam sebagai penyangga kebisingan masih sedang, dimana tanaman pohon pada pekarangan di permukima ditanami beberapa jenis pohon dengan kerimbunan jarang, tinggi pohon rata- rata lebih besar dari 3 meter. Dari hasil pengamatan lapangan di Titik 4 (Jl. Kayu Manis) ditemukan bahwa tingkat peredam ganaman di titik pengukuran ini masih rendah, terlihat perkarangan pemukiman ditanami beberapa jenis pohon bervariasi dengan kerimbunan jarang dengan jarak lebih dari 5 meter dan tinggi pohon rata-rata kurang dari 3 meter. Pada titik 5 (Jl. Pahlawan Kerja Gg.Pala) ditemukan tanaman perkarang pemukiman ditanami beberapa pohon yang bervariasi dengan kerimbunan jarang (lebih dari 5 meter) dan ketinggian pohon masih kurang dari 3 meter. Sehingga disimpulkan bahwa tingkat peredam berupa tanaman pepohonan di pemukiman titik 5 masih rendah. Selanjutnya hasil pengamatan pada titik 6 (Jl. Nur Asiyah) disimpulkan tingkat peredam (pengaman) tanaman pohon masih rendah, terlihat dari dari kerimbunan pohon tanaman di perkarangan pemukiman jarang, ketinggian pohon rata-rata kurang dari 3 meter meskipun tanamannya bervariasi. 
Tabel 9. Kondisi Peredam Bising Barrier Buatan di Lokasi Penelitian

\begin{tabular}{|c|c|c|c|c|c|}
\hline Titik Pengukuran & Atap & Dinding & Pagar & $\begin{array}{l}\text { Tinggi } \\
\text { Bangunan } \\
\text { (m) }\end{array}$ & $\begin{array}{l}\text { Tingkat } \\
\text { Peredam }\end{array}$ \\
\hline Titik 1 & Lembar & Bata & - & $4 \mathrm{~m}$ & Rendah \\
\hline J1. Kaswari & Aluminium & & & & \\
\hline Titik 2 & Lembar & Bata & - & $4 m$ & Rendah \\
\hline Jl.Rawa Indah II & Aluminium & & & & \\
\hline Titik 3 & Lembar & Bata & Semen & $4 m$ & Sedang \\
\hline J1. Rawa Indah & Aluminium & & dan Besi & & \\
\hline Titik 4 & Lembar & Bata & Semen & $5 \mathrm{~m}$ & Sedang \\
\hline J1. Kayu Manis & Aluminium & & dan Besi & & \\
\hline $\begin{array}{l}\text { Titik } 5 \\
\text { J1. Pahlawan Kerja } \\
\text { Gg.Pala }\end{array}$ & $\begin{array}{l}\text { Lembar } \\
\text { Aluminium }\end{array}$ & Bata & $\begin{array}{l}\text { Semen } \\
\text { dan Besi }\end{array}$ & $3,5 \mathrm{~m}$ & Sedang \\
\hline $\begin{array}{l}\text { Titik } 6 \\
\text { J1. Nur Asiyah }\end{array}$ & $\begin{array}{l}\text { Lembar } \\
\text { Aluminium }\end{array}$ & $\begin{array}{l}\text { Bata } \\
(<10 \mathrm{~cm})\end{array}$ & $\begin{array}{l}\text { Kayu, } \\
\text { Semen, } \\
\text { dan Besi }\end{array}$ & $4 \mathrm{~m}$ & rendah \\
\hline
\end{tabular}

Berdasarkan hasil pengukuran tingkat kebisingan di sekitar bandara Sultan Syarif Kasim II diketahui lokasi titik 1 (Jl.Rawa Indah II) mengalami pemaparan kebisingan yang tertinggi. Hasil ini menunjukkan lokasi titik 1 harus mendapat perhatian yang serius bagi masyarakat yang bermukim di sekitar bandara, karena dampak kebisingan bandara berpotensi negative terhadap kehidupan masyarakat pemukiman. Dari hasil pengamatan juga diketahui bahwa tingkat peredam kebisingan masih rendah, baik dari segi tanaman pohon yang ada disekitar pemukiman dan tinggi, dinding dan pagar masih kurang efektif meredam kebisingan.

Dari hasil penelitian yang telah dilakukan, dapat dirumuskan beberapa strategi mitigasi untuk meredam tingkat kebisingan di sekitar bandara Sultan Syarif Kasim II, diantaranya:

a. Menanamkan tanaman yang sesuai dengan kebutuhan pengendalian atau meredam kebisingan di pemukiman maysarakat. Kategori tanaman pohon yang cocok untuk ditanam di area pemukiman sekitar bandara adalah: pohon yang rindang dan dapat ditanam rapat atau banyak daun-daunan yang bisa tumbuh sampai ketinggian sekitar $4-15 \mathrm{~m}$ (seperti akasia, pohon mahoni, flamboyan, pohon ulin atau beringin, bambu atau cemara). Tanaman yang digunakan untuk penghalang kebisingan hingga sampai $95 \%$ harus memiliki kerimbunan dan kerapatan daun yang cukup dan merata mulai dari permukaan tanah hingga ketinggian yang diharapkan [Balitbang PU, 2005). Sebagai contoh, volume kerimbunan daun minimum untuk menghasilkan tingkat reduksi kebisingan 3,4 dBA dengan menggunakan tanaman Sebe (Heliconia $S p$ ) adalah 1,792 $\mathrm{m}^{3}$. Berikut jenis tanaman yang mampu mengurangi tingkat kebisingan dan nilai reduksi kebisingannya. 
Tabel 10. Efektifitas Pengurangan Kebisingan Oleh Berbagai Macam Tanaman

\begin{tabular}{|c|c|c|c|c|}
\hline Jenis Tanaman & $\begin{array}{l}\text { Volume } \\
\text { Kerimbunan } \\
\text { Daun }\left(\mathrm{m}^{3}\right)\end{array}$ & $\begin{array}{l}\text { Jarak Dari } \\
\text { Sumber } \\
\text { Bising ke } \\
\text { Tanaman } \\
\text { (d)(m) }\end{array}$ & $\begin{array}{l}\text { Ketinggian } \\
\text { Pengukuran } \\
\text { (m) }\end{array}$ & $\begin{array}{l}\text { Rata-rata } \\
\text { Reduksi } \\
\text { Kebisingan } \\
\text { IL (dBA) }\end{array}$ \\
\hline & 114,39 & 18,2 & 1,2 & 2,5 \\
\hline Akasia (Accasia & & 30,2 & 4 & 4,1 \\
\hline \multirow[t]{2}{*}{ Mangium) } & 118,23 & 18,2 & 1,2 & 2,7 \\
\hline & & 24,6 & 4 & 4,4 \\
\hline Bambu Pringgodani & 122,03 & 7 & 1,2 & 1,1 \\
\hline (Bambuga Sp) & & 16,4 & 2,5 & 4,9 \\
\hline \multirow{4}{*}{ Johar (Casia Siamea) } & 366,08 & 35,4 & 1,2 & 14,7 \\
\hline & 60,74 & 9,8 & 1.2 & 0,3 \\
\hline & & 17 & 3,6 & 3,2 \\
\hline & 83,24 & 9,6 & 1,2 & 0,2 \\
\hline Likuan - Yu & 2,464 & 8,2 & 1,2 & 2,3 \\
\hline Anak Nakal (Durant & 1,68 & 9,8 & 1,2 & 0,8 \\
\hline \multicolumn{5}{|l|}{ Repens) } \\
\hline Soka & 1,35 & 11,2 & 1,2 & 0,9 \\
\hline Kekaretan & 1,105 & 4,6 & 1,2 & 0,9 \\
\hline Sebe (Heliconia $S p$ ) & 1,792 & 3,2 & 1,2 & 3,4 \\
\hline Teh - tehan & 11,1 & 6 & 1,2 & 3,4 \\
\hline $\begin{array}{l}\text { Disisipkan : } \\
\text { a. Teh-tehan }\end{array}$ & 13,88 & 6 & 1,2 & 2,7 \\
\hline \multirow[t]{3}{*}{ b. Heliconia Sp } & 2,75 & 9 & 1,2 & 3,8 \\
\hline & 16,65 & 6 & 1,2 & 4,2 \\
\hline & 33,3 & 9 & 1,2 & 5 \\
\hline
\end{tabular}

Sumber : Balitbang PU, 2005

b. Untuk mengurangi tingkat kebisingan juga bisa dilakukan dengan membuat noise barrier dengan menggunakan vegetasi buatan. Dari analisis yang dilakukan tersebut ditemukan lokasi titik pengukuran penelitian khususnya titik 2 perlu diterapkan konsep penataan peredam bunyi. Konsep tersebut dapat berupa penggunaan bahan bangunan. sesuai Surat Keputusan Menhub No. 77, tahun 1988. Untuk penutup atap dapat digunakan bahan yang mereduksi kebisingan tertinggi, yaitu Asbes Semen, yang dapat mereduksi bising sebesar $26 \mathrm{dBA}$, menggunakan bahan untuk plafon berbentuk tripleks dengan teba minimal $4 \mathrm{~mm}$, yang dapat mereduksi mereduksi kebisingan sebesar $21 \mathrm{dBa}$, dan menggunakan dinding tembok bata yang berkualitas, yang dapat mereduksi kebisingan horizontal sebesar $40 \mathrm{dBA}$. 


\section{KESIMPULAN}

Secara keseluruhan tingkat kebisingan tertinggi di kawasan pemukiman sekitar Bandara Sultan Syarif Kasim II berada di area landasan pacu utara yaitu pada titik 2 (Jl. Rawa Indah II) yakni rata-rata sebesar 77,80 dB(A). Sedangkan tingkat kebisingan terendah berada pada titik 4 (Jl. Kayu manis) yaitu rata-rata $72,05 \mathrm{~dB}(\mathrm{~A})$. Tingginya tingkat kebisingan di area perumahan ini disebabkan oleh tingginya frekwensi aktivitas penerbangan yang terjadi baik pada saat take off maupun landing. Setelah dilakukan pemetaan, dapat dilihat bahwa penyebaran tingkat kebisingan yang cenderung tinggi berada di pemukiman area landasan pacu utara. Dari 4 (empat) kali pengukuran, sebanyak 3 (tiga) kali hasil pemetaan isodesibel yang menunjukkan hasil yang tinggi berada pada area landasan pacu utara, yaitu pada hari Minggu pertama, Minggu Kedua, dan Senin Kedua.

Kondisi existing peredam kebisingan pada lokasi penelitian masih kurang efektif, hal ini terlihat dari tatanan tanaman yang kurang rimbun dan tata letak yang jarang-jarang. Jika diliat dari kondisi bangunan yang ada masih menunjukkan tingkat peredam yang kurang efektif, hal ini terlihat pada struktur bangunan yang kurang memenuhi (dinding bangunan kurang dari $10 \mathrm{~cm}$ ) dan upaya mitigasi yang dilakukan untuk meredam kebisingan yang dihasilkan oleh bandara dapat dilakukan dengan dua cara, yaitu pertama menanam pohon yang rindang dan memiliki kerapatan daun-daunan serta berpotensi tumbuh sekitar 4 - 15 $\mathrm{m}$ (akasia, mahoni, flamboyan, beringin, bambu), kedua membuat noise barrier dengan menggunakan bahan bangunan berupa Asbes semen, plafon berbahan triplek $4 \mathrm{~mm}$, dan dinding tembok bata yang berkualitas.

\section{UCAPAN TERIMAKASIH}

Penulis menyampaikan terimakasih kepada seluruh pihak yang membantu dalam kelancaran penelitian ini.

\section{DAFTAR PUSTAKA}

Ardina Yullynta Sari. 2009. Pemantauan Kebisingan Dan Efektifitas Pengendalian Yang Ada Di Dapur Peleburan Baja Slab Steel Plant Ii(Ssp Ii) Pt Krakatau Steel Cilegon: Surakarta

Basuki, Heru. 1985. Merancang, Merencana Lapangan Terbang PT Alumni Bandung.

Bachtiar, V. S., Y. Dewilda, B.V. Wemas. 2013. Analisis Tingkat Kebisingan dan Usaha Pengendalian pada Unit Produksi pada Suatu Industri di Kota Batam. Jurnal Teknik Lingkungan UNAND. X (2): 85-93.

Badan Pusat Statistik Provinsi Riau. 2018. Riau Dalam Angka 2018. Pekanbaru

Badan Penelitian dan Pengembangan Departemen Pekerjaan Umum, 2005, Mitigasi Dampak Kebisingan Akibat Lalu Lintas Jalan, Departemen Pekerjaan Umum RI : Jakarta

Berglund, Birgitta dan L. Thomas. 1995. Community Noise . Archives of the Center for Sensory Research. Sweden.

Charlotte Clark, Centre for Psychiatry, "Aircraft noise effects on health", May 2015,https://assets.publishing.service.gov.uk/government/uploads/system/uplo ads/attachment_data/file/446311/noise-aircraft-noise-effects-on- health.pdf

Chimayati, Rachmi Layina, Analysis Of Noise Level Generated By The Activity Of Kualanamu Internasional Airport And Management Efforts (Studi Kasus: Bandara Internasional Kualanamu), Department Of Environmental

Engineering Faculty Of Civil Engineering And Planning Institut Teknologi Sepuluh Nopember, Surabaya 2017

Chaeran, M. 2008. Kajian kebisingan akibat aktifitas di bandara (studi kasus bandara ahmad yani semarang) (Doctoral dissertation, program Pascasarjana Universitas Diponegoro) http://eprints.undip.ac.id/ diunggah 15/09/2020)

Cholidah. 2006. Perbedaan Ambang Pendengaran Tenaga Kerja Setelah Terpapa Kebisingan dan Sesudah Bekerja Pada Lingkungan Bising Departemen Ring Frame Unit Spinning I PT Apacinti Corpora Bawen. 
Ch. Liu., Martelens, 2011, Kondisi Peredam Bising Akibat Lalulintas Pesawat Udara Di Bandar Udara Sultan Hasanuddin Terhadap Aktivitas Masyarakat Di Kawasan Permukiman Sudiang, Jurnal Transportasi Vol. 11 No. 3 Desember 2011 : 183-190

Dirk Schreckenberg, Markus Meis, Cara Kahl, Christin Peschel and Thomas Eikmann;, Aircraft Noise and Quality of Life around Frankfurt Airport', Int. J. Environ. Res. Public Health 2010, 7(9), 33823405 ;

Dirk Schreckenberg, Ursel Heudorf, Thomas Eikmann, dan Markus Meis; Aircraft noise and health of residents living in the vicinity of Frankfurt Airport', Edinburgh, Scotland, EURONOISE 2009, October 26-28.

Dedi Wahyu Nugroho, Pengaruh Intensitas Kebisingan Terhadap Kelelahan Kerja Pada Tenaga Kerja Di Pt. Antam Tbk. Ubpe Pongkor, Bogor, Jawa Barat", Program Diploma Iv Kesehatan Kerja Fakultas Kedokteran Universitas Sebelas Maret Surakarta 2009.

Dewanti, R.A dan Sudarmaji. 2015. Analisis Dampak Intensitas Kebisingan terhdap Pendengar Petugas Laundry. Jurnal Kesehatan Lingkungan. 8 (2) :229- 237

Dwi, P dan Sasongko. 2000. Kebisingan Lingkungan. Badan Penerbit Universitas Diponegoro Semarang. Semarang.

Fauzi A. 2014. Valuasi Ekonomi dan Penilaian Kerusakan Sumberdaya Alam dan Lingkungan. Bogor (ID): IPB Press

Ferial, L., E. Suswanto, S.D.M. Silalahi. 2016. Analisis kebisingan di Terminal Pakupatan (Kabupaten Serang, Provinsi Banten). Jurnal Teknik Lingkungan Trisakti. 8(1):81-96.

Farahnaz Khajenasiri, Alireza Zamanian, and Zahra Zamanian; The Effect of Exposure to High Noise Levels on the Performance and Rate of Error in Manual Activities, 2016 Mar; 8(3): 2088-2093. Published online 2016 Mar 25. doi: [10.19082/2088]

Groothoff, B. 1996. Noise and Vibration-Their Effect and Control. Quensland.

Hiral J. Jariwala, Huma S. Syed, Minarva J. Pandya, and Yogesh M. Gajera;" "Noise Pollution \& Human Health: A Review", uploaded by Hiral Jariwala on 29 August 2017, https://www.researchgate.net/publication/319329633

Harrington dan F.S Gill. 2005. Buku Saku Kesehatan Kerja Edisi 3.Penerbit EGC. Jakarta

Jamrah, Ahmad et al., 2006. Evaluation of Traffic Noise Pollution in Amman, Jordan. Environmental Monitoring and Assessment (2006) 120: 499-525.

Keputusan Menteri Tenaga Kerja. 1999. Keputusan Menteri Tenaga Kerja No. KEP-51/MEN/1999 tentang Nilai Ambang Batas Kebisingan Ditempat Kerja.

Kementerian Negara Lingkungan Hidup, 1996. Keputusan Menteri Negara Lingkungan Hidup. Kep 48/MENLH/11/1996 tentang Baku Tingkat Kebisingan. Jakarta.

Komang, R.A. 2016. Analisis Tingkat Kebisingan di Kawasan Bandara International Sultan Syarif Kasim II Pekanbaru. Skripsi. Universitas Riau.

Nadhillah, R.Z, R. Noor, N. Annisa. 2016. Pemodelan tingkat kebisingan di SD Negeri

Loktabat Utara Kota Banjarbaru. Jurnal Tugas Akhir Mahasiswa Program Studii Teknik Lingkungan Universitas Lambung Mangkurat. 1(1):180-192.

Nawawi, H dan M. Hadari. 1995. Instrumen Penelitian Bidang Sosial. Gadjah Mada University Press. Yogyakarta.

National Institute of Occupational Safety and Health (NIOSH), 2014, Controls For

Noise Exposure,http://www.cdc.gov/niosh/topics/no isecontrol. Diaunggah tanggal $15.09 / 2020$.

Nursusandhari, E. 2009. Persepsi, preferensi, dan willingness to pay masyarakat terhadap lingkungan permukiman sekitar kawasan industri (kasus kawasan industri di Kelurahan Utama, Cimahi, Jawa Barat). Skripsi. Bogor (ID): Institut Pertanian Bogor. 
Prabu. 2009. Dampak Kebisingan Terhadap Kesehatan. Graha Ilmu: Yogyakarta.

Priambodo, L. H. dan M. Najib. 2014. Analisis kesediaan membayar (willingness to pay) sayur organik dan faktor-faktor yang mempengaruhinya. Jurnal Manajemen dan Organisasi 5 (1) : 1 - 14.

Prima Fithri dan Indah Qisty Annisa, "Analisis Intensitas Kebisingan Lingkungan Kerja pada Area Utilities Unit PLTD dan Boiler di PT.Pertamina RU II Dumai", Jurnal Sains, Teknologi dan Industri, Vol. 12, No. 2, Juni 2015, pp. 278 - 285

Putrakusuma D. 2014. Estimasi willingness to pay masyarakat dan formulasi strategi ruang terbuka hijau taman kota Waduk Pluit Jakarta Utara. Skripsi. Institut Pertanian Bogor. Bogor.

Rahayu A. 2013. Eksternalitas negatif akibat kebisingan kereta api terhadap masyarakat di Kelurahan Bekasi Jaya, Bekasi Timur, Kota Bekasi. Skripsi. Institut Pertanian Bogor. Bogor.

Sasmita, A. dan A. David. 2017. Evaluasi Tingkat Kebisingan Di Bandara Sultan Syarif Kasim II Pekanbaru. Jurnal Teknik. 15 (1). 30-35.

Sasongko, D. P. dan Hadiyarto, A., 2000. Kebisingan Lingkungan. Universitas Diponegoro: Semarang.

Suma'mur P.K. 1996. Keselamatan dan Pencegahan Kecelakaan. Jakarta : CV. Gunung Agung.

Tambunan, T. B. 2005. Analisis Tingkat Kebisingan di Tempat Kerja dan Keselamatan Kerja. Jakarta.

Tarwaka, dkk., 2008. Keselamatan dan Kesehatan Kerja. Surakarta: Harapan Press

Tarwaka, H. A. ,S. Bakri dan L. Sudiajeng. 2004. Ergonomi Untuk Keselamatan, Kesehatan Kerja dan Produktivitas. Uniba Press. Surakarta.

WHO. 1999. Guidelines for Community Noise. World Health Organization. Ganeva

Zein, K. dan S. Safrudin. 2018. Analisis Paparan Kebisingan Pesawat Terbang di Bandara Babullah Ternate. NM Environmental Journals. 1 (1) : 39-44. 